\title{
Size structure and fertility in an Eriocnema fulva Naudin (Melastomataceae) population in Southeastern Brazil
}

\author{
Andrade, PM. ${ }^{\mathrm{a} *}$, Santos, FAM. ${ }^{\mathrm{b} *}$ and Martins, FR. ${ }^{\mathrm{b} *}$ \\ anstituto Estadual de Florestas, Rua Espírito Santo, 495, CEP 30160-030, Belo Horizonte, MG, Brazil \\ ${ }^{\text {b} G r u p o ~ d e ~ P e s q u i s a ~ e m ~ E c o l o g i a ~ V e g e t a l, ~ L a b o r a t o ́ r i o ~ d e ~ E c o l o g i a ~ V e g e t a l, ~}$ \\ Departamento de Botânica, Instituto de Biologia, Universidade Estadual de Campinas - UNICAMP \\ CP 6109, CEP 13083-970, Campinas, SP, Brazil \\ *e-mail: fmartins@unicamp.br, priscilaandrade@epamig.br, fsantos@unicamp.br \\ Received April 11, 2005 - Accepted October 17, 2006 - Distributed November 30, 2007
}

(With 3 figures)

\begin{abstract}
Eriocnema fulva Naudin is an endangered perennial herbaceous plant, endemic to Minas Gerais state, Brazil. This study was conducted in the Jambreiro Forest ( $19^{\circ} 58^{\prime}-59^{\prime} \mathrm{S}$ and $43^{\circ} 52^{\prime}-55^{\prime} \mathrm{W}, 800-1100 \mathrm{~m}$ altitude). In an attempt to describe the population size structure and its association with individual fertility, fifteen $1 \times 1 \mathrm{~m}$ contiguous plots were set. We tagged, counted, and measured a total of 260 individuals in 1997, 1998 and 1999. Young individuals with leaf lamina lengths $\leq 3.4 \mathrm{~cm}$ comprised $33 \%$ of the total sampled, indicating that the population was reproducing locally. The number of leaves varied significantly, growth differences being detected only after two years of measurements. Stem length was the variable that best showed population size variation. The length of the largest leaf lamina was the best indication of its development phase. Assessing the number of leaves helped to evaluate the alteration in plant size during the study. The probability that individuals with laminas $\geq 10 \mathrm{~cm}$ in length did not reproduce was $2.69 \%$. The highest survival probability of the large-sized individuals confirmed the strong correlation between size and survival. The data indicated that size is important for the fertility of E. fulva, and it may be one of the relevant aspects to be considered for analyses of survival probability. The intraspecific competition, which was indicated by negative correlation between fruit production per size unit and density, can affect fertility, as larger plants had higher fruit production.
\end{abstract}

Keywords: size, fertility, plant population, intraspecific competition.

\section{Estrutura de tamanho e fertilidade em uma população de Eriocnema fulva Naudin (Melastomataceae) no sudeste do Brasil}

\begin{abstract}
Resumo
Eriocnema fulva é endêmica no estado de Minas Gerais e é ameaçada de extinção. Este estudo foi realizado na Mata do Jambreiro $\left(19^{\circ} 58^{\prime}-59^{\prime} \mathrm{S}\right.$ e $43^{\circ} 52^{\prime}-55^{\prime} \mathrm{W}, 800-1100 \mathrm{~m}$ de altitude) Com o objetivo de descrever a estrutura de tamanho da população e suas relações com a fertilidade dos indivíduos, foram instaladas 15 parcelas contíguas de 1 x 1m. Marcamos, contamos e medimos um total de 260 indivíduos em 1997, 1998 e 1999. Os indivíduos jovens com o comprimento do limbo $\leq 3,4 \mathrm{~cm}$ somaram $33 \%$ do total amostrado, mostrando que a população estava reproduzindose no local. O número de folhas variou significativamente entre os anos, com diferenças de crescimento só detectadas após dois anos de medições. O comprimento do caule foi a variável que melhor mostrou a variação de tamanho na população. O comprimento da lâmina da maior folha foi a melhor expressão da fase de desenvolvimento da planta, e o número de folhas auxiliou na avaliação da alteração do tamanho ao longo do tempo. A probabilidade de indivíduos com limbos foliares $\geq 10 \mathrm{~cm}$ não se reproduzirem foi de 2,69\%. A maior probabilidade de sobrevivência dos indivíduos de maior tamanho confirmou a forte correlação entre tamanho e sobrevivência. Os dados mostraram que o tamanho é importante para a fertilidade de Eriocnema fulva e pode ser relevante para análises de probabilidade de sobrevivência da espécie. A competição intra-específica, indicada pela correlação negativa entre a produção de frutos por unidade de tamanho e a densidade, pode influir na fertilidade, pois plantas maiores apresentaram maior produção de frutos.
\end{abstract}

Palavras-chave: tamanho, fertilidade, população de plantas, competição intra-específica. 


\section{Introduction}

Plant populations are generally not alike; they have different genetic, spatial, age, and size structures. All of these structures are interrelated, and a change in one of them results in modifications to all others (Silvertown and Lovett-Doust, 1993). Size may be the main factor in the fate or fecundity of a plant (Sarukhán et al. 1984, Fowler, 1986; Begon et al., 1996).

In most plant populations, individual size varies tremendously, generally due to the overlapping of generations, as well as other factors. Hence, a size hierarchy asymmetrical size distribution - tends to occur, in which a relatively small number of large individuals contributes to the largest part of the population biomass (Weiner and Solbrig, 1984). Various authors have considered size as the best indicator of plant fitness and the level of population development (Harper and White, 1974; Gatsuk et al., 1980; Silvertown and Lovett-Doust, 1993). Size may be defined as any variable that represents plant mass, such as the volume, height, dry weight, diameter, or any other measurement having an association with the performance of an individual (Solbrig and Solbrig, 1984).

Asymmetric size distributions have important genetic and evolutionary implications (Solbrig and Solbrig, 1984). Fecundity is related to size because plants flower and bear fruit only after reaching a certain size (Harper and White, 1974). In general, plants with a short period of time until their first reproduction are short-lived, while those with a long period are long-lived (Harper and White, 1974). This indicates a relationship of compromise, a trade-off, in the allocation of resources between vegetative growth and reproduction (Solbrig, 1981). Although some exceptions do exist (Hay and Barreto, 1988) and changes in the proportion of biomass allocated to reproduction may occur (Solbrig and Simpson, 1974), larger plants generally have larger fecundity and a greater probability of survival (Solbrig, 1981; Fowler, 1986; Herrera, 1991; Hanzawa and Kaliz, 1993; Silvertown and Lovett Doust, 1993; Begon et al., 1996).

Throughout the 1980's the terms fecundity, fertility, seed production and fruit production were used in an indistinct manner. Herrera (1991) claimed the need to include demographic aspects in population studies in order to evaluate total reproductive success. Caswell (1989) distinguished between the terms fecundity and fertility, using the former as a representation of the maximum reproductive potential and the latter as the actual reproductive performance. In this study, from now on, we will use Caswell's (1989) definition and evaluate the fertility as the actual reproductive performance expressed as the number of fruits per individual. Weiner (1988) showed that the total mass of seeds produced by herbaceous annual plants is directly proportional to the plant size. Several other authors have also shown that seed production is positively correlated with plant biomass (McGraw and Wulff, 1983; Lechowicz and Blais, 1988; Waller, 1988; Geber, 1990; Aarssen and Clauss, 1992; Aarssen and Taylor, 1992; Weiner, 1995). Consequently, larger plants tend to leave more descendants.

Due to the current fragmentation of natural habitats, knowing the size distribution within populations may help to understand species responses to changes caused by fragmentation (Saunders et al., 1991; Bruna and Kress, 2002). Long-term studies dealing with population dynamics are ideal to understand and explain observed patterns. Nevertheless, studies regarding the instantaneous size structure in a population can be done in a shorter period of time and can also provide data capable of identifying general population patterns (Henriques and Souza, 1989).

Eriocnema fulva is listed as an endangered species in the State of Minas Gerais (Conselho Estadual de Política Ambiental, 1997). Currently, the demands relative to the conservation of endangered plant species are many, and studies concerning stage or size structure in populations may serve as a ground for immediate decisions regarding the management of species, mainly when long-term demographic studies are not feasible or not available (Bruna and Kress, 2002). Considering the importance of the relationships between size, fertility, and survival, our objective was to describe the size structure of an E. fulva population and highlight the characteristics of fertility related to the variation in the size of individuals, answering the following questions: 1) What are the size variables that best describe plant development? 2) How is the structure of the sizes within the population arranged? 3) Are fertility and size related? 4) If so, does the relation between fertility and size vary in the population with time? 5) Does fertility in the population vary among years? and 6) Is fertility influenced by plant density?

\section{Material and Methods}

\subsection{Study species}

Eriocnema fulva is a herbaceous species with a prostrate stem. Its geographic distribution is restricted to the State of Minas Gerais, southeastern Brazil. Up to the present, there are records of this species only in the municipalities of Ouro Preto and Sabará (Cogniaux, 1883; Badini, 1940) and Nova Lima (Andrade, 1993). It occurs in groups of individual plants on rock walls along riverbanks shaded by the seasonal semi-deciduous Atlantic Forest. E. fulva does not occur in association with other species of angiosperms, only with few bryophyta and pteridophyta (personal observation). Recent studies show that the reproductive system of this species is selfcompatible; it produces fruit via neither autogamy nor agamospermy, but requires, obligatorily, pollen vectors due to the buzz pollination syndrome (Andrade, 2004). The root system is individualized and vegetative reproduction was not observed.

\subsection{Study area}

This study took place in the Jambreiro Forest (912 hectares), located in the central-southeastern region of Minas 
Gerais State, between $19^{\circ} 58^{\prime}-59^{\prime} \mathrm{S}$ and $43^{\circ} 52^{\prime}-55^{\prime} \mathrm{W}$ in the municipality of Nova Lima, in the metropolitan region of Belo Horizonte. The region of Nova Lima is located in the Quadrilátero Ferrífero, a region with iron ore sites (Alves, 1988). The climate is Koeppen's Cwa, macrothermic temperate with mild summers and dry winters. Rains (1400-1600 mm/year) predominate during the hottest period (October to March), the mean annual temperature is $18{ }^{\circ} \mathrm{C}$, mean maximum temperature is $21^{\circ} \mathrm{C}$, and the mean minimum temperature is $14{ }^{\circ} \mathrm{C}$ (Alves, 1988). The soil is dystrophic Cambisol (Cetec, 1983), the altitudes vary between 800 and $1100 \mathrm{~m}$, and the relief has an undulating topography. This study was conducted in an area adjacent to the water stream Ribeirão do Cardoso, at altitudes around $850 \mathrm{~m}$ (Plambel, 1977). The terrain on which the Jambreiro Forest occurs belongs to the company Minerações Brasileiras Reunidas (MBR) and in August 1998 it was protected as a Reserva Particular do Patrimônio Natural (RPPN), a form of land conservation in Brazil, which started by a legal instrument (Portaria number 070 on September 11, 1998) from the Instituto Estadual de Florestas (IEF), a State environment protection agency in Minas Gerais.

\subsection{Data collection}

Fifteen contiguous $1 \times 1-\mathrm{m}$ plots were set on the rock wall of a riverbank containing a group of $E$. fulva plants. The plots were delimited by cotton twine tied to small nails fixed into the wall. All plants with the largest leaf lamina length greater than or equal to $1 \mathrm{~cm}$ were tagged by a numbered aluminum tag. For each individual the number of leaves was counted, and measures of the petiole length and the width and length of the largest leaf lamina were taken. Stem length was measured for most of the plants, with the exception of small plants, which had stems so reduced that it was not possible to measure them. When this occurred, we stated that the plant was not measurable and represented the stem length as category " 0 ". We also counted the number of fruit present on each plant. The number of seeds present in six capsules of six individuals was counted to estimate the mean number of seeds per fruit per plant. All tagged individuals in the plots were counted and measured in 1997, 1998 and 1999 with intervals of 414 and 363 days, respectively. Measurements taken in 1997 were used to classify individual plants into size classes and to investigate the relationship between fertility and size. In order to verify temporal variation of the number of individuals and the relations between fertility and size, we used the measurements taken in 1997, 1998, and 1999. Measurements were done using a ruler and metric tape.

\subsection{Data analysis}

Analysis of size distribution in the population was based on data collected in 1997. Intervals for the size classes were established based on scatter diagrams. In order to demonstrate the connection between fertility and size we grouped plants measured in 1997 into two categories: vegetative and reproductive. Reproductive plants displayed re- productive structures, such as flowers and fruits. Plants that did not display these structures were considered vegetative. To test whether the size distribution differed between reproductive and vegetative plants, the Mann-Whitney U test was used, including Z (value of the deviation from the normal distribution) because the sample size was larger than 20 individuals (Zar, 1984). To evaluate fertility, the mean number of seeds per capsule $(130.84 \pm 66.82)$ was used. Assuming that this average was representative of the entire population, fertility was estimated for different classes of leaf and stem length considering the number of fruit per plant counted in 1997. For some of the largest leaf size classes, the reproduction probability was calculated with the data obtained in 1997, using the number of individuals that produced fruits. The relationship between survival and size in the vegetative plants was analyzed by considering the proportions of plants that survived between the initial (1997) and final (1999) observations. Size classes were defined based on the distributions of stem length, largest leaf lamina length, and number of leaves. The difference in fruit production between the three years of observations was checked by using the Kruskal-Wallis test on the number of fruit per individual (Zar, 1984). Considering the data collected in 1997, reproductive individuals were divided into two classes based on the number of leaves, largest leaf lamina length and stem lengths. A variance analysis was used to test for differences between the number of fruit produced and the different size classes (Zar, 1984). Associations between measurements of fertility and size were analyzed using linear regression. Regressions were used to test for variation of fertility and size over the three years of the study $(1997,1998$, and 1999). The differences between angular coefficients (b) and intercepts were tested with covariance analyses (ANCOVA) and a posteriori Scheffé test (Sokal and Rohlf, 1969). ANCOVA and Sheffé tests were used only on significant regressions. Covariance analyses were carried out using the ANCOVA program created by F. A. M. Santos. Data from 1997 were also used to test for associations between fertility, size and density. Initially, for each plot, we established the relationship between the largest blade length and the number of fruit by using linear regression (Zar, 1984). The linear regression $(y=a+b x)$ generated an angular coefficient (b) that represented a relationship between the number of fruit and the largest blade length in each plot. After obtaining the angular coefficient (b) for each plot, the Pearson simple correlation was calculated between the angular coefficient (b) and the number of plants per plot (density per plot). The same calculations were made to test for the association between the angular coefficient (b) of the number of fruits vs. the stem length and the density per plot.

\section{Results}

\subsection{Population structure}

Two hundred and sixty individuals were sampled in $15 \mathrm{~m}^{2}\left(17.3 \pm 12.2\right.$ individuals $\mathrm{m}^{-2}$, mean \pm standard deviation), of which $57 \%$ were in the vegetative 
state. Plants in the smallest leaf blade length class $(1 \mathrm{~cm} \leq \mathrm{L} \leq 3.4 \mathrm{~cm})$ predominated and accounted for $33 \%$ of the total number of individuals sampled (Figures 1 and 2a). A predominance of the smallest stem size class also occurred (Figure 2b). The largest number of plants was recorded in the 6-10 $\mathrm{cm}$ leaf number class (Figure 2c). The blade length best described the size of the individual in comparison to the number of leaves, because a small plant could have many small leaves. The length and width of the largest leaf blade, the length of the petiole, the number of leaves, and the length of the stem were the best indicators of morphometrics and plant growth pattern. The parameters of linear regressions between measurements of size were the following: leaf blade length vs. leaf blade width $(\mathrm{n}=260 ; \mathrm{a}=-0.0065 ; \mathrm{b}=0,65$; $\left.\mathrm{r}^{2}=0.95 ; \mathrm{p}<0.001\right)$, leaf blade length vs. petiole length $\left(\mathrm{n}=260 ; \mathrm{a}=-1.53 ; \mathrm{b}=1.28 ; \mathrm{r}^{2}=0.84 ; \mathrm{p}<0.001\right)$, leaf blade length vs. number of leaves $(n=260 ; a=3.95$; $\left.\mathrm{b}=0.93 ; \mathrm{r}^{2}=0.29 ; \mathrm{p}<0.001\right)$, leaf blade length vs. stem length $\left(n=260 ; a=5.66 ; b=0.83 ; r^{2}=0.35 ; p<0.001\right)$, number of leaves vs stem length $(\mathrm{n}=260 ; \mathrm{a}=6.80$;
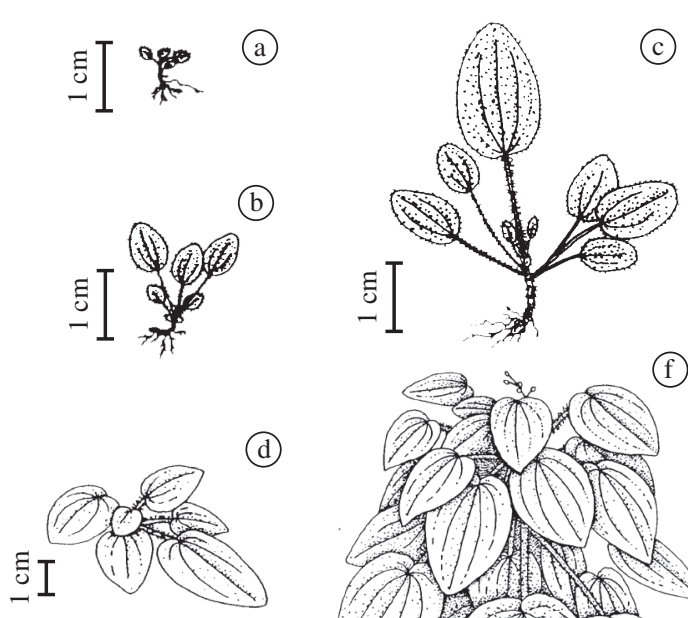

(d)

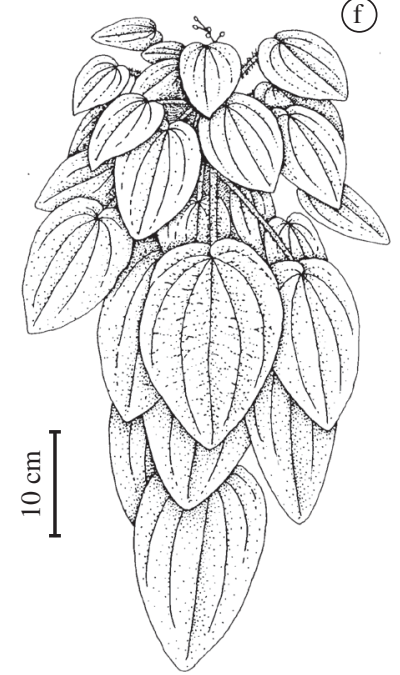

Figure 1. Class sizes for Eriocnema fulva, based on the largest leaf blade length found on plants. a, b) Individuals with blades smaller than $1 \mathrm{~cm}$. c) Individual in the smallest blade length class $(1.5 \mathrm{~cm})$. d) Individual, without stem, with the largest blade length of $4 \mathrm{~cm}$. e) Reproductive individual with reduced stem, the largest leaf blade length is $7 \mathrm{~cm}$. f) Reproductive individual with developed stem, the largest leaf blade is $13 \mathrm{~cm}$ in length. $\left.\mathrm{b}=1.80 ; \mathrm{r}^{2}=0.55 ; \mathrm{p}<0.001\right)$. The significant relation among these variables indicated that they could be used to analyze both the size and growth of each plant and also the population as a whole. These variables were also the best indicators of size classes and population structure. Leaf blade length and stem length were particularly important: they exerted also the highest influence on fertility (Figures $2 \mathrm{a}$ and $2 \mathrm{~b}$ ). The distributions of stem length, largest leaf length, petiole length of the largest leaf, and the number of leaves differed between the vegetative and reproductive categories (Figures 2a, 2b, 2c).

Vegetative plants differed from reproductive plants not only by lacking reproductive structures but also by having smaller sizes. The number of vegetative individuals was 149 and the number of reproductive individuals was 111 . Differences were observed by the Mann-Whitney U test, and were significant for: the stem length of vegetative individuals vs. stem length of reproductive individuals $(\mathrm{U}=398.50 ; \mathrm{Z}=13.12 ; \mathrm{p}<0.001)$, the leaf length of vegetative individuals vs. leaf length of reproductive individuals ( $\mathrm{U}=598.50 ; \mathrm{Z}=-12.78 ; \mathrm{p}<0.001)$, leaf width of vegetative individuals vs. leaf width of reproductive individuals ( $U=562.20 ; Z=-12.84 ; p<0.001)$, number of leaves of vegetative individuals vs. number of leaves of reproductive individuals $(\mathrm{U}=3377.00 ; \mathrm{Z}=-8.15$; $\mathrm{p}<0.001$ ), petiole length of vegetative individuals vs. petiole length of reproductive individuals $(\mathrm{U}=803.00$; $\mathrm{Z}=-12.44 ; \mathrm{p}<0.001)$. However, in spite of this difference, the values overlapped (Figures $2 a, 2 b, 2 c$ ), indicating that in order to separate these two groups, it is necessary to consider also reproductive characters besides size. The vegetative and reproductive categories overlapped in the intermediate-sized plants, and as the individual size increased so did the number of reproductive individuals (Figures 2a, 2b, 2c)

The correlation coefficient (Pearson) for fertility vs. stem length with the density per plot was negative and significant $(\mathrm{r}=-0.67 ; \mathrm{p}<0.05 ; \mathrm{N}=14)$. The Pearson coefficient was also negative and significant in the correlation between fertility vs. largest leaf length with the density per plot (Figure 3, $\mathrm{r}=-0.55 ; \mathrm{p}<0.05 ; \mathrm{N}=15$ ). This negative correlation indicates that an increase in size and fertility was correlated with a reduction in density; i.e., plants of the same size produced less fruits in denser sites. These results indicate that intraspecific competition can influence fertility because larger plants have higher fertility in less dense sites.

\subsection{Vegetative individuals}

Half of the vegetative plants had between 5 and 10 leaves with a maximum of 15 leaves; values above 15 leaves represented extreme values in the overall distribution. Nearly $50 \%$ of the vegetative individuals did not have stems or the stem was at most $1 \mathrm{~cm}$ long, and values of the stem length greater than $1 \mathrm{~cm}$ represented extreme or very extreme values in the overall distribution. The length of the largest leaf varied between 1 and $5 \mathrm{~cm}$, although five individuals had leaf blade lengths greater than $10 \mathrm{~cm}$, which were extreme values in the 


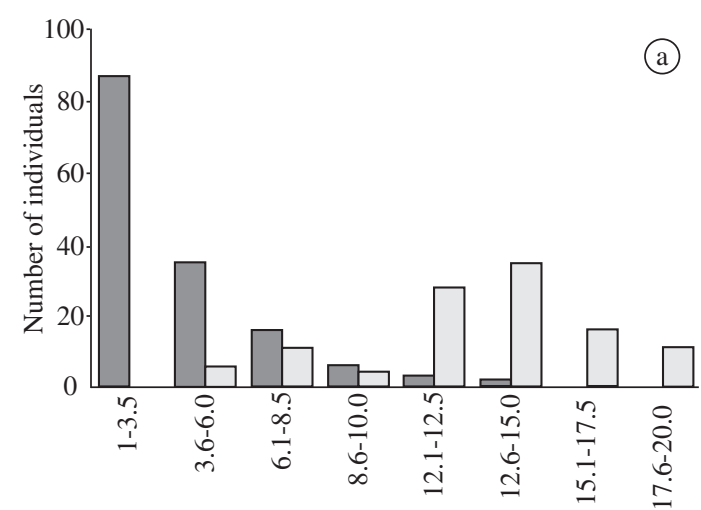

Leaf blade lenght $(\mathrm{cm})$

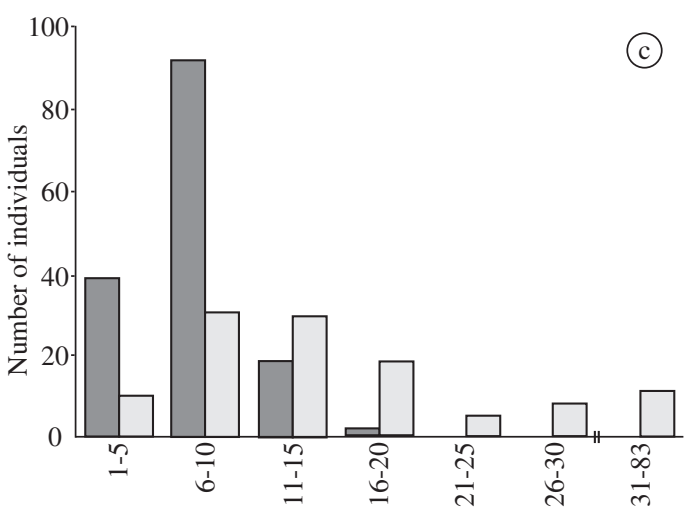

Number of leaves

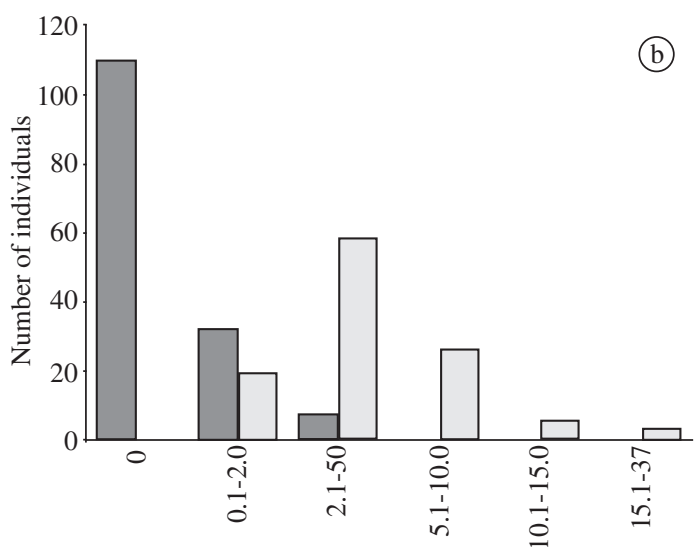

Stem lenght $(\mathrm{cm})$

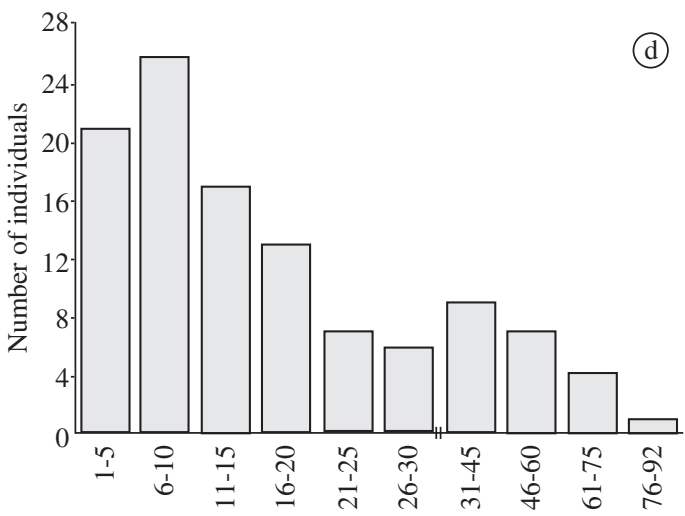

Number of fruits

Figure 2. a) Distribution of the largest leaf blade length. b) Distribution of the stem length. c) Distribution of the number of leaves. Data from the graphs a, b, c are of plants with the largest leaf blade of minimum $1 \mathrm{~cm}$ in a population of Eriocnema fulva (260 individuals $\left./ 15 \mathrm{~m}^{2}\right)$. d) Distribution of the number of fruit from reproductive individuals (111 individuals $\left./ 15 \mathrm{~m}^{2}\right)$. Dark gray bars represent vegetative individuals, light gray bars represent reproductive individuals. All data were collected in the same population in October, 1997.

overall distribution. Nearly $30 \%$ of the vegetative individuals were in the first leaf length class and an everdecreasing number occurred in the remaining classes (Figure 2a).

Vegetative plants could be characterized as possessing a very short, non-measurable stem, the largest blade length smaller than $10 \mathrm{~cm}$, and less than 15 leaves per plant. At a $10 \mathrm{~cm}$ length for the largest leaf, plants were already in the reproductive phase (Figure 2a). As some of the vegetative plants with blade length greater than $10 \mathrm{~cm}$ did not appear healthy, these extreme values could indicate the start of senescence with its resulting loss of vitality in this group. In the vegetative period, the greater the number of leaves, length of the largest leaf and stem length, the greater the proportion of surviving plants between the beginning (1997) and the end of the study (1999). The proportion of surviving plants were the following: leaf length $\leq 3.4 \mathrm{~cm}(80 \%)$, leaf length $>3.4 \mathrm{~cm}(88 \%)$, stem absent $(80 \%)$, stem length $\leq 5 \mathrm{~cm}$
(94\%), number of leaves $\leq 5(65 \%)$, number of leaves $>5$ and $\leq 10(91 \%)$, number of leaves $>10(85 \%)$.

\subsection{Reproductive individuals and fruit production}

Approximately $50 \%$ of the reproductive individuals had the largest blade length between 11 and $15 \mathrm{~cm}$. The smallest length for the largest blade was $4 \mathrm{~cm}$ (Figure 2a). At a length of $10 \mathrm{~cm}$ for the largest leaf blade, the number of reproductive individuals increased and the vegetative individuals decreased considerably (Figure 2a). The probability of individuals with a leaf blade length $\mathrm{L}<10 \mathrm{~cm}$ to reproduce was only $8.07 \%$ and the probability of individuals with $\mathrm{L} \geq 10 \mathrm{~cm}$ not to reproduce was only $2.69 \%$ for the 260 plants sampled. Most of the reproductive plants had measurable, although small (approximately $2.0 \mathrm{~cm}$ ), stems. The proportion of reproductive individuals with a non-measurable or much reduced stem was small (11\%), and $50 \%$ had a stem length between 3 and $6 \mathrm{~cm}$ (Figure 2b). The presence of 


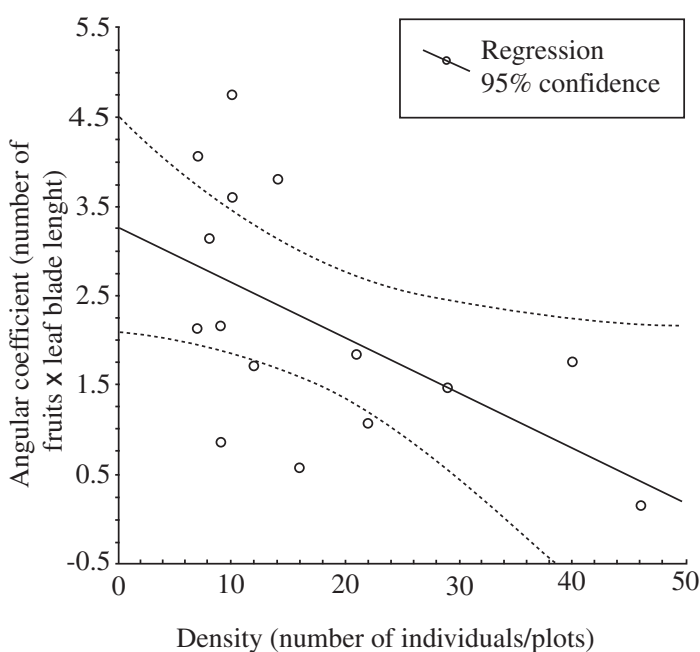

Figure 3. Fruit production per unit length of the largest leaf blade, negatively correlated with density. Lines indicate the interval of confidence. (Pearson coefficient, $\mathrm{r}=-0.55$; $\mathrm{p}<0.05 ; \mathrm{N}=15)$.

a visible stem was a good indicator to identify reproductive individuals, that is, adults. Stem lengths greater than $10 \mathrm{~cm}$ were extreme or very extreme values in the overall distribution. All the plants with more than 21 leaves were reproductive individuals (Figure 2c). Half of the reproductive plants possessed between 10 and 20 leaves and individuals with more than 37 leaves represented extreme values in the overall distribution (Figure 2c). Most individuals, reproductive as well as vegetative, from the entire sampled population had between 5 and 15 leaves. Reproductive plants were characterized as possessing a visible stem, a largest leaf blade length greater than $6 \mathrm{~cm}$, and more than 5 leaves.

The 111 reproductive individuals produced 2,086 pieces of fruit in $15 \mathrm{~m}^{2}$ in 1997 with an average of 40.1 pieces of fruit per plant and a standard deviation of 17.0 , but most plants $(69 \%)$ produced, on average, $9.4 \pm 5.5$ pieces of fruit per individual. Considering only fertile individuals, the distribution of fruit production followed an accentuated hierarchy, with $30 \%$ of the individuals producing $65 \%$ of the fruit total. The production of fruit did not differ between the studied years $\left(\mathrm{H}_{(2, \mathrm{~N}=309)}=0.21 ; \mathrm{p}=0.89\right)$. The stem length, largest blade length, and number of leaves were significantly related to fruit production, although the determination coefficients showed these relationships to be weak, and were partially explained by regression. The parameters of linear regressions were: $\mathrm{N}=$ number of individuals in $15 \mathrm{~m}^{2} ; \mathrm{a}=$ linear coefficient $; \mathrm{b}=$ angular coefficient; $\mathrm{r}^{2}=$ coefficient of determination, $\mathrm{b}$ common $=$ adjusted inclination - used to test differences between the linear coefficients throughout the three years. The regressions for all the years were significant $(\mathrm{p}<0.001)$. The regression results for the number of leaves vs. number of fruit were the following: for $1997(\mathrm{~N}=260 ; \mathrm{a}=-2.03 ; \mathrm{b}=0.90$; $\left.\mathrm{r}^{2}=0.32\right)$, for $1998(\mathrm{~N}=263 ; \mathrm{a}=-2.53 ; \mathrm{b}=0.72$; $\left.\mathrm{r}^{2}=0.34\right)$ and for $1999(\mathrm{~N}=281 ; \mathrm{a}=-4.16 ; \mathrm{b}=0.85$; $r^{2}=0.45$ ). The common angular coefficient (b) was 0.82 and the common linear coefficient (a) was -2.94 . The regression results for blade length vs. number of fruit were the following: for $1997(\mathrm{~N}=260 ; \mathrm{a}=-5.44 ; \mathrm{b}=1.75$; $\left.\mathrm{r}^{2}=0.41\right)$, for $1998(\mathrm{~N}=263 ; \mathrm{a}=-4.78 ; \mathrm{b}=1.47$; $\left.\mathrm{r}^{2}=0.40\right)$ and for $1999(\mathrm{~N}=281 ; \mathrm{a}=-4.69 ; \mathrm{b}=1.55$; $\mathrm{r}^{2}=0.36$ ). The common angular coefficient (b) was 1.59 and the common linear coefficient (a) was -4.94 . The low values of $\mathrm{r}^{2}$ show that the fruit production could also be related to other variables besides those considered in this study.

The covariance analyses throughout all the years of the study $\left(\mathrm{F}_{(\mathrm{df}=2, \mathrm{n}=798)}=1.819 ; \mathrm{p}=0.160\right)$ indicated no significant difference in the relationship between fruit production and the number of leaves. Moreover, the relationship between the number of fruit and the length of the largest leaf blade was not significant among the studied years $\left(\mathrm{F}_{(\mathrm{df}=2, \mathrm{n}=798)}=1.361 ; \mathrm{p}=0.255\right)$, indicating that the associations between fertility and leaves remained the same during the study period.

\section{Discussion}

\subsection{Structure of the population}

Populations of E. fulva occurred discontinuously in space, on rock walls along the banks of streams, where the environment was shady and humid and temperatures were mild (personal observation). This same discontinuous pattern appears to occur, on a smaller scale, within the sampled area, which had large density variations. The differences in density could be related to the environmental heterogeneity of the understory, according to studies conducted on palm trees in tropical habitats (Chazdon, 1986; Chazdon and Pearcy, 1991). E. fulva is an herbaceous species that is a rosette in its young phase (rosette hemicryptophyte) and becomes, with the growth of the stem, prostrate (chamaephyte) in its adult phase. The average area occupied by a plant on a rock wall is small. Possibly, the intensity of light is a fundamental factor to explain the spatial distribution of the population, and its role in the survival of individuals needs closer scrutiny. We observed that an opening in the canopy near a group of individuals $500 \mathrm{~m}$ far from the study site increased the luminosity and resulted in the death of many individuals after three months (personal observation).

The vegetative plants with the smallest length of the largest leaf blade made up $33 \%$ of the individuals in the population studied. The occurrence of a large proportion of young individuals suggested that the population was actively reproducing on site. However, we are not able to say whether the population was growing or stable, because an analysis based on solely the size of individuals, as we did in this study, provides only a momentary and partial view of the overall population patterns (Watkinson, 1986). The structure of size should only be used in order to describe the general patterns of the pop- 
ulation and is not appropriate to make predictions about the past or the future of the population (Whitmore, 1975). Long-term studies analyzing the mortality and growth of young and adult individuals are fundamental in order to make any inference regarding population cycles or the maintenance of stability in tropical species.

Stem length was the variable with the greatest variation in the whole population. The length of the largest leaf blade was the best indicator of size during the development phase of the plant, and the number of leaves was a subsidiary variable, which was important to describe size alteration over time. The number of leaves varied significantly between years, increasing slowly, with differences in growth only detected after two years of measurements, indicating a variation in the population structure over time.

\subsection{Vegetative individuals}

Vegetative individuals had a wide variation of size, ranging from very small to large plants, with a largest leaf blade length varying from 1 to $10 \mathrm{~cm}$. As the growth of the plant is slow, these differences indicate the long period that an individual might take to be able to store enough energy to reproduce. It is well known that plants only flower and produce fruit after reaching a certain size, and that all species go through a period after germination during which they are unable to flower (Harper and White, 1974). The size difference between vegetative and reproductive individuals would indicate that accumulating energy is necessary before reproducing, and that such an accumulation could only be achieved by an increase in size. A great survival probability of the largest individuals was expected, as a strong correlation between survival and size was found in other studies regarding arboreal (Hutchings, 1997) and herbaceous plants (Solbrig, 1981).

\subsection{Reproductive individuals and fruit production}

After attaining a size in which the stem is apparent, has more than five leaves, and the largest leaf length blade is $4 \mathrm{~cm}$ or larger, the E. fulva plant may start its reproductive period. An individual with the largest leaf blade length equal to $1 \mathrm{~cm}$ at the first observation in 1997 reproduced for the first time after two and a half years. We could not record the time necessary for this plant to achieve a length of the largest leaf blade of $1 \mathrm{~cm}$. Close to this individual, there were many other plants with $1 \mathrm{~cm}$ for the length of the largest blade, but they did not grow during the study. This indicates that an E. fulva plant can remain a long time without growing, stagnated at a certain size, until it has conditions to grow and reproduce. Results from seed germination in the greenhouse showed that, after 20 months, the seedling leaf blade was smaller than $1 \mathrm{~cm}$ in length (personal observation). Although it was not possible to estimate the minimum time required for the first reproduction of E. fulva, we believe this is longer than four years. We noticed that very particular environmental conditions are necessary for the survival of this species and its growth is slow, and concluded that the first reproduction might occur in plants with different chronological ages. In general, plants with precocious reproduction have short lives, while plants with delayed reproduction are long-lived (Harper and White, 1974). This could occur due to an alternating strategy of energetic investment towards vegetative growth or reproduction. As E. fulva is an iteroparous species and its first reproduction is delayed, it is probably long-lived.

The probability of individuals with a leaf blade length $\geq 10 \mathrm{~cm}$ not to reproduce was $2.69 \%$, and size differences between vegetative and reproductive plants were significant. However, it was not possible to distinguish ontogenetic stages during the vegetative period by external characters. Moreover, the transition to the reproductive stage was not rigorously characterized, and variations in leaf length and number of leaves occurred continuously from vegetative to reproductive plants. In some species, it is difficult or even impossible to identify the differences between stages and phases in the pre-reproductive period, because leaf structure, branches, and root systems hardly change during this period (Gatsuk et al., 1980). Thus, attaining a minimum size is important for E. fulva to reproduce, but the transition to the reproductive stage could possibly occur as a consequence of favorable environmental conditions. The regularity of fruit production over the years could have, as partial causes, the lack of large environmental variations in the study site and the plant's slow growth, thus indicating the necessity for observations of the population for a longer period of time than used in this study.

Plant size is an important component of plant fitness, with consequences for survival and fecundity (Harper and Bell, 1979; Weiner and Thomas, 1986). However, we observed reproductive individuals with large stems producing a number of fruit similar to individuals with smaller stems. Alternating energetic investments (trade-offs) between growth and reproduction are well known in plant biology (Harper and White, 1974; Solbrig, 1981) and individuals often need to allocate resources among competing demands. The balance between reproduction and other activities manifests as the costs of reproduction, and there is no one single solution to maximize fitness (Silvertown and Lovett Doust, 1993). On one hand, it is likely that for E. fulva the energetic costs of increasing fruit production after a certain age or size are high and not compensated; but on the other hand, the probability of individual survival could be greater if energy were instead directed towards growth (Silvertown and Lovett Doust, 1993). That is, as the plant size increases, the survival chances also increase, although fertility does not increase after a certain size has been reached. Therefore, the high fertility and higher survival probability of larger plants represent an advantage for the E. fulva population.

Intraspecific competition could influence fertility, as indicated by the negative correlation of the number of fruit per size unit with density. The high density of the population in some plots could also reinforce intraspecific competition, and in some sites E. fulva could even 
show the pattern of competition for light seen in monocultures at high densities (Weiner and Thomas, 1986). A demographic study of Heliconia acuminata, an herbaceous species from the Amazon, demonstrated that a reduction in plant size caused by fragmentation resulted in reduced fruit production (Bruna and Kress, 2002). Allometric studies of Rumex obtusifolia L. concerning the relationship between vegetative and reproductive biomass indicated that the increase in reproductive biomass was slower than the increase in vegetative biomass and that, consequently, the reproductive effort decreased with the increase in plant size (Pino et al., 2002). Although controversies do exist, the authors discussed the patterns observed using the associations between reproductive cost, reproductive effort and size. The associations between these variables could be the explanation for the patterns we observed for E. fulva, but a discussion on the costs of reproduction is beyond the scope of this present study. Even without a continuous increase in fruit production in the larger class sizes, our data showed that size is important for the fertility of E. fulva. Furthermore, our data indicated that density is a factor correlated to size that also affects fruit production. Thus, plant size is one of the relevant variables to be considered in the analysis of survival probabilities for the species, because a population with large individuals would produce more fruit, increasing recruitment chances.

We described general patterns of only one population of E. fulva studied at the RPPN Mata do Jambreiro, based on data relative to individual size structure over time. Our results constitute the first information regarding the structure of a population for this threatened species, but it is necessary to conduct long-term studies and studies of other populations to complement our results in order to better understand variations caused by both spatial and temporal differences. Only after such studies it will be possible to understand the general aspects described in this study. Profoundly studying this species will allow for it to be better situated within the various biology and plant population approaches.

Acknowledgments - We are grateful to the National Council of Scientific and Technological Development (CNPq) for a scholarship awarded to the first author. We would like to thank the Instituto Estadual de Florestas (IEF) for logistical help with the research and Minerações Brasileiras Reunidas for permission to work in the reserve.

\section{References}

AARSSEN, LW. and CLAUSS, MJ., 1992. Genotypic variation in fecundity allocation in Arapidopsis thaliana. J. Ecol., vol. 80, no. 1, p. 109-114.

AARSSEN, L. and TAYLOR, DR., 1992. Fecundity allocation in herbaceous plant. Oikos vol. 65 no. 2, p. 225-232.

ALVES, WA., 1988. Carta do meio ambiente e sua dinâmica da microbacia do córrego do Cardoso, Nova Lima, MG. Monografia. Belo Horizonte, Instituto de Geociências, UFMG.
ANDRADE, PM., 1993. Estrutura do estrato herbáceo de trechos da Reserva Biológica Mata do Jambreiro, Nova Lima,MG. (Tese de Mestrado) - Instituto de Biologia, UNICAMP, Campinas, São Paulo, Brasil.

ANDRADE, PM., 2004. Biologia de uma população de Eriocnema fulva Naudin (Melastomataceae). (Tese de Doutorado) - Instituto de Biologia, UNICAMP, Campinas. São Paulo, Brasil.

BADINI, J., 1940. Contribuição à geobotanica das Melastomataceas ouropretanas. Revista Farmaceutica de Ouro Preto. Ano I N. ${ }^{\text {os }} 4$ e 5 P8.

BEGON, M., HARPER, JL. and TOWNSED, CR., 1996. Ecology: individuals, populations and communities. $3 \mathrm{rd}$ ed. Blackwell Science, Oxford.

BRUNA, EM. and KRESS, WJ., 2002. Habitat fragmentation and the demographic structure of an Amazonian understory herb (Heliconia acuminata). Conservation Biology. vol. 16, no. 5 , p. 1256-1266.

CASWELL, H., 1989. Matrix population models. Sinauer, Sunderland.

CETEC. FUNDAÇÃO CENTRO TECNOLÓGICO DE MINAS GERAIS, 1983. Mapa 3/ Solos. Diagnóstico ambiental do estado Minas Gerais. Fundação Centro Tecnológico de Minas Gerais, Comissão de Política Ambiental. Belo Horizonte. MG.

CHAZDON, RL., 1986. Light variation and carbon gain in rainforest understory palms. Journal of Ecology, vol. 74, no. 4, p. $995-1012$.

CHADZON, RL. and PEARCY, RW., 1991. The importance of sunflecks for forest understory plants. BioScience, vol. 41, no. 11 , p. $760-766$.

COGNIAUX, A., 1883. Melastomataceae Tribus I Microlicieae Triana. In MARTIUS,CFP. de, ENDLICHER, S.,EICHLER, AG. and URBAN, J.(ed.) 1840/1906. Flora brasiliensis:enumerativo plantarum in Brasilia. V. 14, t.3. Lipsiae apud Frid. Fleischer in comm, Monachii.

CONSELHO ESTADUAL DE POLITICA AMBIENTALCOPAM., 1997. Aprova lista das espécies ameaçadas de extinção da flora do Estado de Minas Gerais. Deliberação COPAM N ${ }^{\circ} 85$. Belo Horizonte, Minas Gerais. vol. 105, no. 206, p. 10-12.

FOWLER, NL., 1986. Density-dependent population regulation in a Texas grassland. Ecology, vol. 67, no. 2, p. 545-554.

GATSUK, E., SMIRNOVA, OV., VORONTZOVA, LI. and ZAUGOLNOVA, LA., 1980. Age states of plants of various growth forms: a review. Journal of Ecology, vol. 68 no. 2, p. 675-96.

GEBER, MA., 1990. The cost of meristem limitation in Polygonum arenastrum: negative genetic correlations between fecundity and growth. Evolution, vol. 44, no. 4, p. 799-819.

HANZAWA, FM. and KALISZ, S., 1993. The relationship between age, size, and reproduction in Trillium grandiflorum (Liliaceae). American Journal of Botany, vol. 80, no. 4, p. 405-410.

HARPER, JL. and BELL, AD., 1979. The population dynamics of growth form in organisms with modular construction. In ANDERSON, RM., TURNER, BC. and TAYLOR, LR. (Eds.). Population dynamics. Blackwell, Oxford. p. 29-52. 
HARPER, JL. and WHITE, J., 1974. The demography of plants. Annual Review of Ecology and Systematics, vol. 5, p. 419-463.

HAY, JD. and BARRETO, EJM., 1988. Natural mortality of Vochysia thyrsoidea in an unburnt cerrado ecosystem near brasília. Biotropica, vol. 20, no. 4, p. 274-279.

HENRIQUES, RPB. and SOUZA, ECEG., 1989. Population structure, dispersion and microhabitat regeneration of Carapa guianensis in northeastern Brazil. Biotropica, vol. 21 no. 3, p. 204-209.

HERRERA, CM., 1991. Dissecting factors reponsible for individual variation in plant fecundity. Ecology, vol. 72, no. 4, p. 1436-1448.

HUTCHINGS, MJ., 1997. The structure of plant populations. In CRAWLEY, MJ. (ed.) Plant ecology, p. 325-358. 2nd. Ed. Blackwell Scientific, Oxford.

LECHOWICZ, MJ. and BLAIS, PA., 1988. Assessing the contributions of multiple interacting traits to plant reproductive success environmental dependence. Journal of Evolutionary Biology, vol. 1, no. 3, p. 255-273.

MCGRAW, JB. and WULFF, RD., 1983. The study of plant growth; a link between physiological ecology and population biology of plants. Journal of Theoretical Biology, vol. 103, no. 1, p. 21-28.

PLAMBEL., 1977. Carta de Belo Horizonte. Escala 1:25.000. RMBH 20/32 Folha SE 23-ZC-VI-3-SO Superintendência da Região Metropolitana de Belo Horizonte. Planejamento Região Urbana de Belo Horizonte Convênio PLAMBEL/SECT COPASA/ CETEL/ CEMIG.

PINO, J., XAVIER SANS, F. and MASALLES, RM., 2002. Size-dependent reproductive pattern and short-term reproductive cost in Rumex obtusifolius L. Acta Oecologica, vol. 23, no. 5, p. 321-328.

SAUNDERS, DA., HOBBS, RJ. and MARGULES, CR., 1991. Biological consequences of ecosystem fragmentation; a review. Conservation Biology, vol. 5, no. 1, p.18-32.

SARUKHÁN, J., MARTINEZ-RAMOS, M. and PIÑERO, D., 1984. The analysis of demographic variability at individual level and its populacional consequences. In DIRZO, R. and SARUKHÁN, J. (ed.) Perspective on plant population ecology. Massachusetts, Sinauer Ass. Sunderland.
SILVERTOWN, JW. and LOVETT DOUST, J., 1993. Introduction to plant population ecology (3rd ed.). Blackwell, Cambridge.

SOKAL, RR. and ROLHF, JF., 1969. Biometry. San Francisco, W. H. Freeman and Company.

SOLBRIG, OT., 1981. Studies on the population biology of the genus Viola. II. The effects of plant size on fitness in Viola sororia. Evolution, vol. 35, no. 6, p. 1080-1093.

SOLBRIG, OT. and SIMPSON, BB., 1974. Components of regulation of a population of dandelions in Michigan. Journal of Ecology, vol. 62, no. 2, p. 473-486.

SOLBRIG, OT. and SOLBRIG, DJ., 1984 Size inequalities and fitness in plant populations. In R. DAWKINS and M. RIDLEY (Eds.) Oxford Surveys in Evolutionary Biology. Oxford, vol. 1, p. 141-159.

WALLER, DM., 1988. Plant morphology and reproduction. In LOVETT DOUST, J. and LOVETT DOUST, L. (eds) Plant, reproductive ecology: patterns and strategies. Oxford Univ. Press. New York, p. 203-227.

WATKINSON, AR., 1986. Plant population dynamics. in CRAWLEY, MJ. (ed.) Plant ecology. Blackwell Scientific Publ., Oxford, p. 137-184.

WEINER, J., 1988. Variation in the perfomance of individuals in plant populations. In DAVY, AJ., HUTCHINGS, MJ. and WATKINSON, AR. (eds). Plant population ecology. Blackwell. Oxford. p 59-81.

WEINER, J., 1995. Following the growth of individuals in crowded plant populations. Trends of Ecology and Evolution, vol. 10 , no. 10 , p. 389-390.

WEINER, J. and SOLBRIG, OT., 1984. The meaning and measurement of size hierarchies in plant populations. Oecologia, vol. 61 no. 3, p. 334-336.

WEINER, J. and THOMAS, SC., 1986. Size variability and competition in plant monocultures. Oikos, vol. 47, no. 2, p. 211-222.

WHITMORE, TC., 1975. Tropical rain forest of the far east. Clarendon Press, Oxford.

ZAR, H., 1984. Biostatistical analysis. $2^{\text {nd }}$ edn. London: Prentice-Hall International Editions. 